\title{
Financial Free in the Retirement Period by Saving on Stocks
}

\author{
Glenn Brillian Putra Herman Fernando ${ }^{1 *}$, Agung Prabowo ${ }^{2}$ \\ ${ }^{1,2}$ Department of Mathematics, Faculty of Mathematics and Natural Sciences, Universitas Jenderal Soedirman, \\ Jl. dr. Suparno Utara No. 61 Grendeng Purwokerto, 53122, Indonesia \\ Corresponding author e-mail address: glennbrillian@ gmail.com*
}

\begin{abstract}
This study aims to calculate the minimum estimate of saving stocks per month to be financially free after 30 years of investing in stocks. The research method used is a quantitative method. The results showed that the estimated minimum funds to get passive income of 5 million, which is equivalent for the next 30 years, is IDR 930,936 per month.
\end{abstract}

Keywords: financial free, retirement, saving stocks.

\section{Introduction}

Many people are not financially free when they have retired from a job. Someone is said to be financially free if that person can live on passive income without the need to work. Therefore, people need to invest. One type of investment is stock investment.

Stock is a evidence of partial ownership of a company to investors or traders who invest funds in a company. One of the characteristics of shares is that the owner of the shares can earn dividends. Dividends are part of the profits that the company gets distributed to shareholders (Azis et al., 2015; Dai et al., 2020; Hughes et al., 2019).

Stocks ownership can be bought and sold, one of which is on the Indonesia Stock Exchange. The share price is influenced by the volume of purchases and sales volume. If the buying volume is more than the selling volume, then the share price increases. Conversely, the volume of purchases is less than the volume of sales, the price falls. Therefore, share prices are volatile (easy to change) (Hidayat, 2011; Alessie et al., 2004; Gao et al., 2017; Jiang and Kim, 2005).

The share price is also influenced by the net profit of a company. When the net income of a company increases every year, the share price also continues to increase. If the company can increase profits every year, the shares are worth investing in for the long term (Sulisyanto, 2008; Oyedokun et al., 2019; Iyappan and Ganesamoorthy, 2020; Al Nuaimi et al., 2019).

This study aims to calculate the minimum estimate of saving stocks per month to be financially free after 30 years of investing in stocks. 


\section{Methodology}

This section discusses the present value and future value, the estimated needs of a family every month, the estimated inflation every year, and the estimated stock interest earned every year.

This research uses quantitative methods. The data required in this study are the annual net profit of the BCA and BRI banks, the highest annual share value, inflation from 2015-2019, and the market capitalization of BCA and BRI banks. The research steps used are as follows:

\section{Stage 1: Present Value and Future Value}

Present value (PV) is the present value determined by the future value. On the other hand, the future value (FV) is the future value which is determined by the present value (Pramono, 2007; GasparsWieloch, 2019; Zaree et al., 2020; Tharani and Uthayakumar, 2020). The formula for the present value is:

$$
P V=\frac{F V}{(1+i)^{n}}
$$

where:

$i \quad$ : interest rate per period

$n$ : time period

\section{Stage 2: Estimated Needs Every Month}

When you retire, it is important to know how much money you use each month to make ends meet. If the need for funds is not estimated, the pension funds will run out.

The pension fund needed by each person varies depending on the lifestyle. In this article, it is assumed that the amount of pension money (funds) for a family is IDR 5,000,000 each month (Table 1).

Table 1.Estimated pension fund in one month

\begin{tabular}{lr}
\hline \multicolumn{1}{c}{ Budget Allocation } & Amount (IDR) \\
\hline Food & $1,000,000.00$ \\
Electricity, water and gas & $500,000.00$ \\
Vehicle tax & $400,000.00$ \\
Fuel & $300,000.00$ \\
Recreational Fees & $500,000.00$ \\
Property tax & $300,000.00$ \\
Savings & $1,000,000.00$ \\
Miscellaneous expense & $1,000,000.00$ \\
\hline Total & $5,000,000.00$ \\
\hline
\end{tabular}

Stage 3: Estimated Inflation Each Year

Almost every year, Indonesia experiences inflation. Inflation is an indicator of changes in the value of a currency. For example, 10 years ago IDR 25,000 was used to buy $1.5 \mathrm{~kg}$ of eggs, whereas now the same amount of money is only enough to buy $1 \mathrm{~kg}$ of eggs. 
Therefore, inflation forecasts are needed to estimate the future value of the currency. The average inflation for 5 years from 2015-2019 can be seen in Table 2. From Table 2, it is found that the annual increase in inflation for the 5 years from 2015 to 2019 is $6.64 \%$. This figure is used as the annual inflation rate for 30 years.

Table 2.Inflation in Indonesia, 2014-2019

\begin{tabular}{cc}
\hline Year & Inflation $(\%)$ \\
\hline 2015 & 13.66 \\
2016 & 6.03 \\
2017 & 5.28 \\
2018 & 4.59 \\
2019 & 3.92 \\
\hline Average inflation per year & 6.64 \\
\hline
\end{tabular}

Source: https://www.bi.go.id/id/moneter/inflasi/data/Default.aspx

\section{Stage 4: Estimated Stock Interest Earned Each Year}

A company is said to be healthy when the net profit earned by the company continues to increase every year. A healthy company is expected to keep increasing share prices every year. The author uses the market capitalization indicators in selecting stocks, namely market capitalization greater than 10 trillion and stock interest greater than $15 \%$ within the first 5 years when the IPO (Initial Public Offering). Other indicators is stock interest rate.

Market capitalization is the number of shares multiplied by the share price in that company. The greater the market capitalization, the less likely one or more people will control large amounts of shares (for example $10 \%$ of market capitalization). Thus, stock prices are more stable when the market capitalization is large. The formula for finding the stock's interest value is

$$
i_{s}=\sqrt[n]{\frac{H S_{x}}{H S_{x-n}}}
$$

where

$i_{s} \quad:$ the increase of share price per year

$n \quad$ : time period

$H S_{x} \quad$ : stock price in year $x$

$H S_{x-n}:$ Share price in year $(x-n)$

\section{Results and Discussion}

In this article, the highest stock price is used each year because the author tries to see the stock price when the company is performing well. The author does not estimate stock prices for the next few days or months because stock prices are strongly influenced by the number of buyers and sellers of shares. 
Next, two stocks that meet the requirements were selected, namely shares of PT Bank Central Asia Tbk (BBCA) and PT Bank Rakyat Indonesia (BBRI). The first requirement is a market capitalization of more than 10 trillion and BBCA and BBRI meet the first requirements. The market capitalization of BBCA and BBRI can be seen in Table 3.

Table 3. Market capitalization

\begin{tabular}{lc}
\hline Stocks & Market Capitalization (IDR in Trillions) \\
\hline BBCA & 497,130 \\
BBRI & 247,020
\end{tabular}

Source: https://idx.co.id/data-pasar/ringkasan-perdagangan/ringkasan-saham/

The second condition is that the stock interest rate is greater than $15 \%$ in the first five years. The stock price after five years until the share price in 2019 is used to determine the increase in share prices each year. The increase in BBCA and BBRI stock prices can be seen in Table 4 and Table 5. Based on Table 4 and Table 5, the share interest rate in the first five years for BBCA and BBRI shares is $29.59 \%$ and BBRI is $60.08 \%$, respectively. Both figures are greater than $15 \%$, so the second condition is met.

Table 4. BBCA Stock Price

\begin{tabular}{ccr}
\hline Year & Highest Stock Price (IDR) & Stock Interest Per Year (\%) \\
\hline 2005 & 1,950 & \\
2009 & 5,500 & 29.593140 \\
2010 & 7,200 & 30.909090 \\
2011 & 8,850 & 22.916670 \\
2012 & 9,500 & 7.344633 \\
2013 & 11,400 & 20.000000 \\
2014 & 13,575 & 19.078950 \\
2015 & 15,600 & 14.917130 \\
2016 & 16,200 & 3.846154 \\
2017 & 22,750 & 40.432100 \\
2018 & 26,975 & 18.571430 \\
2019 & 34,000 & 26.042630 \\
\hline $2010-2019$ & Increase in stock price per year & 18.820000 \\
\hline \multicolumn{3}{c}{}
\end{tabular}

Table 5.BBRI Stock Price

\begin{tabular}{ccc}
\hline Year & Highest Stock Price (IDR) & Stock Interest Per Year (\%) \\
\hline 2003 & 132.5 & \\
2007 & 870.0 & 60.075860
\end{tabular}




\begin{tabular}{ccr}
2008 & 780.0 & -10.344800 \\
2009 & 870.0 & 11.538460 \\
2010 & $1,280.0$ & 47.126440 \\
2011 & $1,450.0$ & 13.281250 \\
2012 & $1,570.0$ & 8.275862 \\
2013 & $1,990.0$ & 26.751590 \\
2014 & $2,440.0$ & 22.613070 \\
2015 & $2,690.0$ & 10.245090 \\
2016 & $2,595.0$ & -3.531600 \\
2017 & $3,720.0$ & 43.352600 \\
2018 & $3,920.0$ & 5.376344 \\
2019 & $4,730.0$ & 20.663270 \\
\hline $2008-2019$ & Increase in stock price per year \\
\hline \multicolumn{3}{c}{}
\end{tabular}

Furthermore, the author will see if the stock price rises in the following year the company's net profit also increases. BBCA and BBRI net income can be seen in Table 6 and Table 7.

We can see that one of the criteria for selecting stocks is influenced by company profits except for BRI shares in 2008 and 2016. In 2008, BRI's highest decline in share price decreased by 10.35\%. Share prices fell due to the global financial crisis (PT Bank Rakyat Indonesia, 2008). In 2016, BRI's highest share price decline decreased by $3.53 \%$. Share prices fell because the smallest increase in net income from 2007-2019 was 2016.

Furthermore, the author will estimate the minimum amount of funds that need to be invested every month, so that someone gets a passive income of 5 million per month within 30 years.

Suppose the author takes the share price per year from 2008-2019 BRI bank is $17.8 \%$ with an inflation rate of $6.64 \%$. Furthermore, the author will estimate the total stock fund needed for the next 30 years.

The first step, the author will estimate the total stock fund that will be taken every year after 30 years of investing in stocks.

Table 6.BBCA's Net Profit

\begin{tabular}{ccc}
\hline Year & Net Profit Per Year (Trillion IDR) & Annual Net Profit Increase (\%) \\
\hline 2005 & 3.598 & \\
2009 & 6.807 & 17.27992 \\
2010 & 8.479 & 24.56295 \\
2011 & 10.820 & 27.60939 \\
2012 & 11.721 & 8.32717 \\
2013 & 14.254 & 21.61078 \\
2014 & 16.486 & 15.65876 \\
2015 & 18.000 & 9.18355 \\
2016 & 20.600 & 14.44444 \\
2017 & 23.300 & 13.10680 \\
2018 & 25.900 & 11.15880 \\
2019 & 28.600 & 10.42471 \\
\hline
\end{tabular}

Source: PT Bank Central Asia Tbk., (2009), PT Bank Central Asia Tbk, (2014), and PT Bank Central Asia Tbk., (2019)

Table 7.BBRI's Net Profit

\begin{tabular}{ccc}
\hline Year & Net Profit Per Year (Trillion IDR) & Annual Net Profit Increase (\%) \\
\hline 2003 & 2.579 & \\
\hline
\end{tabular}




\begin{tabular}{lcc}
\hline 2007 & 4.838 & 17.03173 \\
2008 & 5.958 & 23.15006 \\
2009 & 7.308 & 22.65861 \\
2010 & 11.472 & 56.97865 \\
2011 & 15.088 & 31.52022 \\
2012 & 18.687 & 23.85339 \\
2013 & 21.160 & 13.23380 \\
2014 & 24.176 & 14.25331 \\
2015 & 25.204 & 4.25215 \\
2016 & 25.753 & 2.17823 \\
2017 & 28.469 & 10.54634 \\
2018 & 32.400 & 13.80800 \\
2019 & 34.400 & 6.17284 \\
\hline
\end{tabular}

Source: PT Bank Rakyat Indonesia Tbk., (2008), PT Bank Rakyat Indonesia Tbk., (2012), PT Bank Rakyat Indonesia Tbk., (2017), and PT Bank Rakyat Indonesia Tbk., (2019)

The estimated total stock fund for each year after 30 years of investing in stocks is:

$$
\begin{aligned}
& 100 \%+i_{i}=(100 \%-a)\left(100 \%+i_{s}\right) \\
& 106.7 \%=(100 \%-a)(117.8 \%) \\
& a=9.42 \%
\end{aligned}
$$

where

$a$ : stock fund estimates are taken annually after 30 years of stock investing

$i_{i} \quad$ : estimated increase in inflation every year

$i_{s} \quad$ : estimated increase in share prices each year

So, the estimated total equity fund after 30 years of investing in stocks is $9.42 \%$.

The second step, the writer will estimate the total stock fund needed at this time (present value). The total share fund needed at this time is:

$$
\begin{aligned}
& P V=P V_{12} \times 12 \times \frac{1}{a} \\
& P V=\operatorname{IDR} 5,000,000 \times 12 \times \frac{1}{9.42 \%} \\
& P V=\operatorname{IDR} 637,200.00
\end{aligned}
$$

where

$P V_{12} \quad$ : monthly needs in a family.

The estimate that the total required share fund currently is IDR 637,200,000.00. Furthermore, the authors will estimate the value of IDR 637,200,000.00 in the next 30 years, namely

$$
\begin{aligned}
& F V=P V \times\left(1+i_{i}\right)^{n} \\
& F V=\text { IDR } 637,200,000 \times(1+6.7 \%)^{30} \\
& F V=\text { IDR } 637,200,000 \times 7 \\
& F V=\text { IDR 4.2604 billion }
\end{aligned}
$$


It is estimated that the total stock fund needed after 30 years of investing in stocks is IDR 4.4604 billion. Furthermore, the author will estimate how much minimum funds each month in order to obtain shares of IDR 4.4604 billion within 30 years.

$$
\begin{aligned}
& I M=\left(\frac{F V}{(1+i)^{30}+(1+i)^{29}+\ldots . .+(1+i)}\right)\left(\frac{1}{12}\right) \\
& I M=\left(\frac{\mathrm{Rp} 4.4604 \text { billiom }}{(1+0.1391)^{30}+(1+0.1391)^{29}+\ldots . .+(1+0.1391)}\right)\left(\frac{1}{12}\right) \\
& I M=\text { IDR 930,936 per month }
\end{aligned}
$$

where

IM : funds are invested into stocks every month

$i \quad$ : estimated increase in stock interest per year

The estimated fund needed to invest in stocks each month is IDR 930,936 per month. The total funds that can be withdrawn after 30 years of investing in stocks is IDR 4.4604 billion multiplied by $9.42 \%=$ 420.169 million / year or IDR 35,014 million / month.

\section{Conclussion}

From this research it can be concluded that the estimated minimum funds to get passive income of 5 million which is equivalent for the next 30 years is IDR 930,936 per month.

\section{References}

Alessie, R., Hochguertel, S., \& Soest, A. V. (2004). Ownership of stocks and mutual funds: A panel data analysis. Review of Economics and Statistics, 86(3), 783-796.

Al Nuaimi, Q. A. (2019). Aviation Risk Management to Estimation and Forecasting Share Price of Air France. $A L$ Anbar University journal of Economic and Administration Sciences, 11(25), 550-556.

Azis, M., Mintarti, S., \& Nadir, M. 2015. Manajemen Investasi Fundamental, Teknikal, Perilaku Investor, dan Return Saham (Fundamental Investment Management, Technical, Investor Behavior, and Stock Returns). Yogyakarta: Deepublish.

Dai, Z., Zhou, H., Wen, F., \& He, S. (2020). Efficient predictability of stock return volatility: The role of stock market implied volatility. The North American Journal of Economics and Finance, 52, 101174.

Hughes, T. P., Kerry, J. T., Baird, A. H., Connolly, S. R., Chase, T. J., Dietzel, A., \& Kerswell, A. (2019). Global warming impairs stock-recruitment dynamics of corals. Nature, 568(7752), 387-390.

Hidayat, T. (2011). Kamus Populer Istilah Investasi (Popular Dictionary of Investment Terms) Jakarta: Mediakita.

Iyappan, R., \& Ganesamoorthy, L. (2020). Relationship Between Accounting Variables and Share Price Movement 
of Information Technology Industry-A Special Reference to Liquidity. Studies in Indian Place Names, 40(19), 619-624.

Gao, G. P., Moulton, P. C., \& Ng, D. T. (2017). Institutional ownership and return predictability across economically unrelated stocks. Journal of Financial Intermediation, 31, 45-63.

Gaspars-Wieloch, H. (2019). Project net present value estimation under uncertainty. Central European Journal of Operations Research, 27(1), 179-197.

Jiang, C. X., \& Kim, J. C. (2005). Trading costs of non- US stocks on the New York Stock Exchange: The effect of institutional ownership, analyst following, and market regulation. Journal of Financial Research, 28(3), 439459.

Oyedokun, G. E., Arotolu, O. A., \& Vincent, H. (2019). The Determinant of Equity Share Price and the Listed Deposit Money Banks in Nigeria. Journal of Accounting and Strategic Finance, 2(2), 127-142.

Pramono, P.R. (2011). Seri UKM: Gandakan Uang dengan Prinsip Time Value of Money (UKM Series: Duplicate Money with the Principle of Time Value of Money). Jakarta: Elex Media Komputindo.

PT Bank Central Asia Tbk., (2009). Maintaining Solidity Amidst Challenges. Jakarta: PT Bank Central Asia Tbk.

PT Bank Central Asia Tbk., (2014). Providing Added Value in the Middle of a Transition Period. Jakarta: PT Bank Central Asia Tbk.

PT Bank Central Asia Tbk., (2019). Navigating Change. Jakarta: PT Bank Central Asia Tbk.

PT Bank Rakyat Indonesia Tbk., (200177). What Do More Than 30 Million Customers of The Best Bank in Indonesia Have in Common. Jakarta: PT Bank Rakyat Indonesia Tbk.

PT Bank Rakyat Indonesia Tbk., (2012).Good Governance and Innovation: Our Foundationfor Sustainability Development . Jakarta: PT Bank Rakyat Indonesia Tbk.

PT Bank Rakyat Indonesia Tbk., (2017). Fostering The Nation Through Integrated Banking Solution and MSME Transformation. Jakarta: PT Bank Rakyat Indonesia Tbk.

PT Bank Rakyat Indonesia Tbk., (2019).Never Stop Developing and Empowering the Small to Mean More for the Country. Jakarta: PT Bank Rakyat Indonesia Tbk.

Sulisyanto, S. (2001). Earnings Management: Theory and Empirical Model. Jakarta: Grasindo.

Tharani, S., \& Uthayakumar, R. (2020). A novel approach to safety stock management in an integrated supply chain with controllable lead time and ordering cost reduction using present value. RAIRO-Operations Research, 54(5), 1327-1346.

Zaree, M., Kamranrad, R., Zaree, M., \& Emami, I. (2020). Project scheduling optimization for contractor's Net present value maximization using meta-heuristic algorithms: A case study. Journal of Industrial Engineering and Management Studies, 7(2), 36-55. 